\title{
Aktywność społeczna i kariera zawodowa osób niepełnosprawnych ruchowo
}

\section{Social activity and professional career of physically disabled people}

\begin{abstract}
Streszczenie:
Osoby niepełnosprawne muszą zmagać się z wieloma trudnościami i ograniczeniami. Napotykają one na swojej drodze bariery, które w znacznym stopniu utrudniają im normalne funkcjonowanie w przestrzeni społecznej. Często narażone są one dodatkowo na zmianę celów oraz planów życiowych, a niekiedy i całego życia. Wśród osób niepełnosprawnych możemy znaleźć jednostki, które nie potrafią poradzić sobie z własną niepełnosprawnością, ale również takie, które nie porzuciły swoich pasji i wciąż chcą się rozwijać. Jedną z takich osób jest Jarosław Kailing - członek kadry narodowej w parawioślarstwie, który mimo doznanego wypadku cały czas walczy i wygrywa (zarówno w sporcie, jak i życiu).
\end{abstract}

Słowa kluczowe: niepełnosprawność, niepełnosprawność ruchowa, rehabilitacja, aktywność zawodowa, parawioślarstwo

\begin{abstract}
:
Handicapped people have to encounter many difficulties and limitations. They are facing barriers, which mostly impede their normal life in public space. They often need to change their plans or even the whole life. However, amongst them we can either find individuals who cannot handle their own disability or the ones that have never given up their dreams and passions, still heading for self-development. One of them is Jarosław Kailing - the member of the Polish National Team in adaptive rowing who, despite the accident he experienced, is still fighting and winning (both in sport and life).
\end{abstract}


Angelika Pawlaczyk - Aktywność społeczna i kariera zawodowa...

Keywords: disability, physical disability, rehabilitation, professional activity, adaptive rowing

\section{Wprowadzenie}

Niepełnosprawność jest zjawiskiem, które dotyka wiele osób niezależnie od wieku, płci czy innych czynników. Ze względu na jej wielowymiarowość nie można definiować jej w sposób jednoznaczny. Dlatego ważne jest, aby spojrzeć na ten problem nie tylko z medycznego, ale również ze społecznego punktu widzenia'.

Jednym z rodzajów niepełnosprawności jest niepełnosprawność ruchowa. Może ona wynikać m.in. z nieprawidłowego funkcjonowania narządu ruchu, co w znacznym stopniu utrudnia wykonywanie nawet prostych czynności życiowych. Z niepełnosprawnością ruchową kojarzone są przede wszystkim osoby, które w przeszłości uległy wypadkowi i od tego czasu poruszają się na wózku inwalidzkim. Niewiele osób zdaje sobie jednak sprawę z tego, że wynika ona $\mathrm{z}$ wielu schorzeń i dysfunkcji różnych układów ciała człowieka². Niewystarczająca wiedza na ten temat oraz brak świadomości, z jakimi utrudnieniami i ograniczeniami muszą radzić sobie osoby niepełnosprawne, ma wpływ na stereotypowe ich postrzeganie przez społeczeństwo.

Aktywność społeczna jest niezwykle ważna podczas powrotu niepełnosprawnych do normalnego życia. Niestety nie zawsze mogą się oni spotkać z prawidłowymi postawami innych ludzi. Nie każdy człowiek chce pomagać i wspierać. Zdarzają się również tacy, którzy dyskryminują bliźnich ${ }^{3}$. Jednak zdecydowana większość osób podejmuje działania mogące mieć wpływ na dalszy rozwój osoby niepełno-

\footnotetext{
${ }^{1}$ M. Karaś, Niepełnosprawność, od spojrzenia medycznego do społecznego i Disability Studies, „Przegląd Prawniczy, Ekonomiczny i Społeczny” 2012, nr 4, s. 31-32.

2 W. Otrębski, B. Różnowski, Sytuacja psychologiczna osób z niepełnosprawnościq na rynku pracy, Lublin 2008, s. 17.

${ }^{3}$ S. Kowalik, Psychospołeczne podstawy rehabilitacji osób niepełnosprawnych, Warszawa 1996, s. 162.
} 
sprawnej. Do tej grupy zalicza się nie tylko rodzinę czy znajomych, ale również fizjoterapeutów, pracodawców i innych niepełnosprawnych.

W powrocie do normalnego życia niezwykle ważną rolę odgrywa również rehabilitacja. Powołując się na pracę Stanisława Kowalika, należy wyróżnić pięć jej typów. W niniejszym artykule szerzej zostają omówione dwa - rehabilitacja zawodowa i ruchowa. Mają one prowadzić przede wszystkim do usprawnienia osoby niepełnosprawnej w wymiarze biologicznym, psychologicznym i społecznym ${ }^{4}$. W przypadku rehabilitacji ruchowej bardzo ważną rolę odgrywa sport. Dzięki niemu niepełnosprawni mogą nie tylko poprawić swoją sprawność fizyczną, ale również mogą rozwijać się w wybranej przez siebie dyscyplinie sportowej, m. in. poprzez zwiększoną liczbę treningów, udział w zawodach i współzawodnictwo $\mathrm{z}$ innymi sportowcami ${ }^{5}$. Jedną z osób, które mimo doznanego poważnego urazu kręgosłupa nie porzuciły swoich marzeń o sportowej karierze, jest Jarosław Kailing członek kadry narodowej w para-wioślarstwie. Jego aktywność społeczna i kariera zawodowa zostaną przedstawione w ostatniej części niniejszego artykułu.

\section{Niepełnosprawność ruchowa czyli walka z ograniczeniami}

Zgodnie z art. 2 pkt. 10 Ustawy z dnia 27 sierpnia 1997 r. o rehabilitacji zawodowej i społecznej oraz zatrudnianiu osób niepełnosprawnych (Dz. U. 2011, Nr 127, poz. 721 z późn. zm.) niepełnosprawność oznacza:

(...) trwałą lub okresową niezdolność do wypełnienia ról społecznych z powodu stałego lub długotrwałego naruszenia sprawności organizmu, w szczególności powodującą niezdolność do pracy ${ }^{6}$.

Jednym z jej rodzajów jest niepełnosprawność ruchowa. Często to właśnie ona jest kojarzona z osobami z ograniczonymi możliwościami

\footnotetext{
${ }^{4}$ Ibidem, s.31.

5 Ibidem.

6 http://www.niepelnosprawni.pl/ledge/x/1808 [dostęp: 29-12-2016].
} 
Angelika Pawlaczyk - Aktywność społeczna i kariera zawodowa...

poruszania się, tj. poruszającymi się na wózkach bądź o kulach inwalidzkich. Jednak jej zasięg jest o wiele szerszy, gdyż niepełnosprawność ta może być związana z dysfunkcją różnych układów ciała człowieka i wieloma schorzeniami. Niepełnosprawność ruchowa może wynikać np. z nieprawidłowego funkcjonowania narządu ruchu. Nieprawidłowości pojawiają się, gdy kręgosłup, kończyny górne lub kończyny dolne nie wypełniają prawidłowo swoich funkcji, co w znacznym stopniu utrudnia lub uniemożliwia poruszanie się, lub wykonywanie podstawowych czynności. Taki typ niepełnosprawności może mieć charakter wrodzony lub nabyty

Stan, w którym organizm człowieka nie jest w stanie prawidłowo wypełniać swoich podstawowych funkcji, jest niezależny od jego woli i niestety w znacznym stopniu może to wpływać na jego życie codzienne ${ }^{8}$. Oprócz utrudnień pojawiających się podczas wykonywania prostych czynności, ograniczenia te przenoszą się również na życie w wymiarze społecznym: na kontakty międzyludzkie, na postrzeganie osób niepełnosprawnych ich postrzeganie przez społeczeństwo ${ }^{9}$. Niepełnosprawni podczas swojej aktywności społecznej mają do czynienia z różnymi postawami ludzi: od wyrażających chęć pomagania i likwidowania barier po tych dyskryminujących. Ta druga postawa, według Stanisława Kowalika, przejawia się nierównością oraz kategoryzacją społeczną. W związku z tym badacz wyróżnia następujące działania dyskryminacyjne:

- dystansowanie się,

- dewaluowanie,

- delegitymizacja,

- segregacja,

- eksterminacja10.

7 W. Otrębski, B. Różnowski, Sytuacja psychologiczna..., op. cit., s. 17.

${ }^{8}$ S. Kowalik, Psychospołeczne podstawy..., op. cit., s. 25.

9 E. Syrek, Niepełnosprawność - wybrane aspekty jakości życia i promocji zdrowia, [w:] E. Nycz (red.), Niepełnosprawni czy sprawni inaczej - partnerstwo zamiast wykluczenia społecznego, Opole 2003, s. 123-124.

10 S. Kowalik, Psychospołeczne podstawy..., op. cit., s. 162-164. 
Pierwsze działanie - dystansowanie się - jest jedną z najłagodniejszych praktyk dyskryminacyjnych, w przypadku której unika się po prostu kontaktów z niepełnosprawnymi. Kolejne polega już na doszukiwaniu się złych cech u osoby niepełnosprawnej (zwykle nieistniejących), które mogą skutkować np. niechęcią społeczną. Taki negatywny stosunek do niepełnosprawnych może doprowadzić do wprowadzenia pewnych ograniczeń, np. pozbawienia praw, co regulowane będzie odpowiednimi przepisami. W takim przypadku można mówić o delegitymizacji. Kolejne praktyki to segregacja polegająca na izolowaniu osób niepełnosprawnych od społeczeństwa oraz eksterminacja, która ze względu na biologiczne wyniszczanie ludzi uważana jest za najbardziej skrajną ${ }^{11}$. Ze względu na istnienie praktyk dyskryminacyjnych niezwykle ważne jest wsparcie społeczne. Taki rodzaj interakcji może mieć zbawienny wpływ na przezwyciężenie sytuacji kryzysowych, które mogą pojawiać się u niepełnosprawnych ${ }^{12}$. Jednak jednym z najważniejszych działań na rzecz osób niepełnosprawnych fizycznie jest rehabilitacja, której głównym zadaniem jest udzielanie pomocy potrzebującym. To właśnie dzięki aktywności fizycznej niepełnosprawni mogą zmierzyć się oraz pokonać słabości i bariery, które uniemożliwiają im prowadzenie normalnego życia. W związku z przyjętymi standardami rehabilitacja powinna spełniać kilka wymogów, aby można było ją uznać za efektywną i skuteczną, powinna m.in. skupiać się na możliwościach osoby niepełnosprawnej, a nie na jej dysfunkcjach $^{13}$. Ze względu na różne jej ukierunkowania Stanisław Kowalik wyróżnia:

- rehabilitację leczniczą,

- rehabilitację społeczną,

- rehabilitację pedagogiczną,

11 Ibidem.

12 J. Belzyt, Niepełnosprawność - Edukacja - Dorosłość: studium przypadku osoby ociemniałej, Kraków 2012, s. 24.

${ }_{13}$ M. Koper, T. Tasiemski, Miejsce sportu w procesie rehabilitacji osób niepełnosprawnych fizycznie, „Niepełnosprawność - zagadnienia, problemy, rozwiązania” 2013, nr 3 (8), s. 113-114. 
Angelika Pawlaczyk - Aktywność społeczna i kariera zawodowa...

- rehabilitację zawodową,

- rehabilitację ruchową ${ }^{14}$.

Celem pierwszej jest przede wszystkim poprawienie ogólnego stanu zdrowia osoby niepełnosprawnej i zapobieganie wyniszczaniu organizmu. Kolejna - społeczna - m. in. pomaga w powrocie do normalnego życia oraz zaangażowania się w życie społeczne ${ }^{15}$. Pozostałe dwie - rehabilitacja zawodowa oraz ruchowa - ze względu na tematykę artykułu wymagają szerszego omówienia.

\subsection{Osoba niepełnosprawna w przestrzeni społecznej}

Posiadanie kwalifikacji oraz wykonywanie pracy jest niezwykle ważne dla każdego człowieka. Dlatego istotną rolę w przypadku osób niepełnosprawnych pełni rehabilitacja zawodowa. Tomasz Majewski oraz Barbara Szczepankowska wyróżniają kilka jej etapów:

- poradnictwo zawodowe,

- przygotowanie do pracy,

- zatrudnienie,

- opieka nad zatrudnioną osobą niepełnosprawną ${ }^{16}$.

W pierwszym etapie ocenie poddane zostają zdolności do pracy. To właśnie od udzielenia odpowiednich wskazówek i właściwego ukierunkowania osoby niepełnosprawnej przez doradcę zależeć będzie powodzenie i późniejsze efekty przebytej rehabilitacji. Kolejnym krokiem jest przygotowanie do pracy. Na podstawie uzyskanych wcześniej wyników ustala się, w jakim kierunku powinna kształcić się i doszkalać zainteresowana osoba. Po zdobyciu wiedzy teoretycznej oraz odpowiednich umiejętności dokonywana jest weryfikacja miejsc pracy i zatrudnia się osobę niepełnosprawną na stanowisko, które odpowiada jej sprawnościom i kwalifikacjom. Cały proces kończy się w mo-

${ }^{14}$ S. Kowalik, Psychospołeczne podstawy..., op. cit., s. 30-31.

15 Ibidem.

16 T. Majewski, B. Szczepankowska, Rehabilitacja zawodowa osób niepełnosprawnych, [w:] A. Ostrowska (red.), B. Szczepankowska, Problem niepetnosprawności w poradnictwie zawodowym, Warszawa 1998, s. 23-24. 
mencie zdobycia pracy. Jednak do zadań doradcy należy w dalszym ciągu sprawowanie opieki nad podopiecznym oraz udzielanie mu pomocy (szczególnie w okresie adaptacyjnym) ${ }^{17}$.

Konstytucja RP gwarantuje każdemu człowiekowi prawo do pracy. Mimo że osoby niepełnosprawne mają takie same prawa jak pozostali obywatele, to wciąż niestety osób aktywnych zawodowo jest niewiele ${ }^{18}$. Wynika to prawdopodobnie $\mathrm{z}$ tego, że nie są one świadome leczniczego oddziaływania pracy na człowieka. Brzmi to dość naiwnie, jednak i w tym przypadku funkcjonujące w języku polskim powiedzenie „praca uszlachetnia” jest jak najbardziej trafne. Joanna Sosnowska w swoim artykule pisze o tym, jakie znaczenie ma dla osoby niepełnosprawnej aktywność zawodowa; mowa jest m. in. o leczniczych, psychologicznych i zawodowych korzyściach płynących z wykonywania pracy. Autorka wyjaśnia, że:

(...) praca oraz szeroko rozumiana aktywność zawodowa jest bardzo ważnym aspektem funkcjonowania człowieka, gdyż daje poczucie mocy, sprawstwa, bycia potrzebnym, niezależnym oraz stanowi ważny element sukcesu $\mathrm{w}$ drodze do samorealizacji ${ }^{19}$.

co można uznać za potwierdzenie leczniczego oddziaływania pracy. Oprócz tego uważa się, że osoby niepełnosprawne, które są czynne zawodowo, mogą szybciej dostrzec swoje postępy i efekty rehabilitacji. Wynika to przede wszystkim z tego, że chcąc realizować się w pracy i osiągać dobre wyniki, osoby te niejednokrotnie muszą sobie radzić w sytuacjach trudnych. Dzięki temu niepełnosprawni mogą poznać i zmierzyć się ze swoimi lękami i słabościami, osiągnąć sukces i tym samym podnieść swoją samoocenę oraz poczucie własnej wartości ${ }^{20}$.

Wyrównywaniem szans osób niepełnosprawnych m. in. w przestrzeni społecznej zajmuje się Państwowy Fundusz Rehabilitacji Osób

\footnotetext{
17 Ibidem.

18 J. Sosnowska, Znaczenie podjęcia aktywności zawodowej w życiu osoby niepełnosprawnej, „Studia Gdańskie. Wizje i rzeczywistość” 2011, t. 8, s. 260-261.

19 Ibidem, s. 264.

20 Ibidem, s. 264-266.
} 
Angelika Pawlaczyk - Aktywność społeczna i kariera zawodowa...

Niepełnosprawnych (PFRON). Dzięki dostępnym środkom może on np.:

- tworzyć nowe miejsca pracy,

- tworzyć zakłady pracy chronionej,

- likwidować bariery architektoniczne, które obecnie w znacznym stopniu utrudniają niepełnosprawnym podjęcie pracy,

- wspierać osoby chcące rozpocząć własną działalność,

- pomagać w przekwalifikowaniú21.

W przypadku osób o ograniczonych możliwościach poruszania się muszą one zmagać się niestety z większą ilością przeciwwskazań co do podjęcia i wykonywania wymarzonej pracy. Dodatkowo, jeśli niepełnosprawność została nabyta, to zmuszone są one do zrezygnowania z pracy w wyuczonym zawodzie i przekwalifikowania, co wiąże się z dodatkowymi utrudnieniami. Rehabilitacja oraz wynikająca z niej niewystarczająca dyspozycyjność i mobilność w znacznym stopniu utrudniają osobom niepełnosprawnych wejście na rynek pracy ${ }^{22}$.

Mimo że obecnie tworzy się warunki do większej aktywności zawodowej osób niepełnosprawnych, to niestety informacja o rynku pracy oraz wsparciu dla nich nie jest na tyle wyczerpująca, by mogły one korzystać z takiej pomocy bez obawy np. przed utratą przyznanych świadczeń. Ma to również związek z tym, że osoba niepełnosprawna może spotkać się z akceptacją lub odrzuceniem ze strony osób zdrowych. W związku z tym Anna Kotlarska-Michalska wyodrębnia np. nieufność, dystans, nietolerancję czy wrogość jako zachowania wskazujące na drugą - negatywną postawę ludzi mających styczność z niepełnosprawnymi. Wiąże się to prawdopodobnie z funkcjonującymi stereotypami, w których to osoba niepełnosprawna uważana jest

21 Źródło stanowi Raport o sytuacji osób niepełnosprawnych w Polsce, który zamieszczony został na stronie Centrum Badań i Rozwoju Kształcenia w zakładce „Publikacje - Opracowania", http://www.cbe.ahe.lodz.pl [dostęp: 30-12-2016].

22 P. Wolski, Niepełnosprawność ruchowa: między diagnozq a działaniem, Warszawa 2013, s. 14-15. 
za słabszą, a co za tym idzie również za wyizolowaną społecznie ${ }^{23}$. Nieco inaczej postrzegana jest ona w otoczeniu rodziny czy osób, z którymi ma styczność na co dzień zarówno w życiu prywatnym, zawodowym, jak i towarzyskim, ponieważ jak twierdzi A. KotlarskaMichalska:

W obrębie takich małych grup inwalida ma szansę zaprezentowania swoich możliwości zawodowych, towarzyskich i innych cech, które mogą jakby „odwrócić uwagę" od jego inwalidztwa ${ }^{24}$.

Stan zdrowia uważany jest za jedną z najważniejszych życiowych wartości. Ludzie w pełni sprawni bez żadnych przeszkód mogą realizować swoje cele życiowe i podążać ścieżkami przez siebie wyznaczonymi. Nie napotykają na swojej drodze barier, które w jakiś sposób mogłyby ograniczać ich prawidłowe funkcjonowanie w społeczeństwie. Niepełnosprawni - przeciwnie. Oprócz wielu utrudnień, które już w dużym stopniu uniemożliwiają im normalne życie i egzystowanie w społeczeństwie, narażeni są dodatkowo na zmianę swoich celów i planów życiowych. Niepełnosprawność w dużym stopniu wpływa więc na karierę zawodową osób niepełnosprawnych. Muszą one borykać się z niewystarczającą liczbą miejsc pracy, które są dla nich dostępne i dostosowane do ich potrzeb, a oferty pracy często nie zaspokajają w pełni ich potrzeb ${ }^{25}$. Badacze - Wojciech Otrębski i Bohdan Różnowski - zajmujący się sytuacją niepełnosprawnych na rynku pracy twierdzą, że:

Najczęstsze bariery zatrudnialności to stereotypy i uprzedzenia dotyczące osób niepełnosprawnych podzielane przez większość pracodawców, obejmujące przekonania o niskim poziomie wykształcenia i kwalifikacji osób niepełnosprawnych, ich niskiej produktywności, licznych ograniczeniach mobilności osób z niepełnosprawnością 26 .

${ }^{23}$ A. Kotlarska-Michalska, Człowiek niepetnosprawny jako „inny” w ujęciu koncepcji socjologicznych i w świetle badań socjologiczno-psychologicznych, „Roczniki Socjologii Rodziny 1999, t. 11, s. 89.

24 Ibidem.

25 W. Otrębski, B. Różnowski, Sytuacja psychologiczna..., op. cit., s. 16.

26 Ibidem, s. 28. 
Angelika Pawlaczyk - Aktywność społeczna i kariera zawodowa...

Niestety społeczeństwo i pracodawcy często zapominają o tym, że niepełnosprawność wcale nie oznacza posiadania niewystarczających umiejętności przez pracownika niepełnosprawnego. Przeciwnie. Pełnosprawność zawodowa zależy przede wszystkim od stworzonych przez pracodawcę warunków. Jeśli te są odpowiednie, to osoba niepełnosprawna nie napotyka żadnych przeszkód na swojej drodze i może wykonywać swoją pracę w należyty sposób. Często okazuje się, że to właśnie motywacja czy chęć osiągnięcia sukcesu zawodowego stają się motorem do udowadniania przez osobę niepełnosprawną swojej pełnosprawności zawodowej. Samo podjęcie pracy daje nie tylko możliwość poprawy jakości życia, ale także poczucie przynależności do społeczeństwa. ${ }^{27}$ Jak wynika z badań przeprowadzonych przez Małopolskie Obserwatorium Polityki Społecznej, to właśnie możliwość samorealizacji, zyskania satysfakcji, poczucia niezależności, nowych znajomości, a także podniesienie swojej samooceny uważane są za najczęstsze powody poszukiwania pracy przez osoby niepełnosprawne 28 .

\subsection{Zawód: sportowiec}

Rehabilitacja ruchowa powinna przede wszystkim prowadzić do ogólnej poprawy stanu zdrowia. Oprócz tego do jej zadań należy jeszcze usprawnienie osoby niepełnosprawnej - nie tylko w wymiarze biologicznym, ale również psychologicznym i społecznym. Ważną rolę odgrywa tutaj sport ${ }^{29}$.

Można mówić o całym szeregu zalet płynących z uprawiania sportu przez osoby niepełnosprawne: począwszy od utrzymania prawidłowej formy (zarówno tej fizycznej, jak i psychicznej) po zapewnienie sobie poczucia samorealizacji. W późniejszych etapach rehabilitacji zauważyć można, że mimo początkowych obaw czy też niechęci nie-

\footnotetext{
27 M. Czerw-Bajer, W. Duda, D. Kukla, Osoby niepełnosprawne w systemie edukacji i poradnictwa zawodowego, Warszawa 2011, s. 108-111.

${ }^{28}$ Zespół Małopolskiego Obserwatorium Polityki Społecznej, Praca i integracja społeczna osób niepełnosprawnych w województwie małopolskim, Kraków 2011, s. 35.

${ }^{29}$ S. Kowalik, Psychospołeczne podstawy..., op. cit., s. 31.
} 
pełnosprawni chcą już nie tylko poprawiać swoją sprawność, ale również współzawodniczyć z innymi osobami, a co za tym idzie - realizować swoje marzenia i osiągać wyznaczone cele. W artykule autorstwa Anny Mędrak, Joanny Piętak oraz Tomasza Łosienia analizowane są m.in. czynniki mające wpływ na rozwój psychomotoryczny dziecka niepełnosprawnego ruchowo. Według autorów aktywność fizyczna „podnosi i utrzymuje sprawność” oraz „rozwija zdolności komunikacyjne i interpersonalne”, a współzawodnictwo, treningi i zawody „uczą tolerancji, szacunku do ludzkich niedoskonałości oraz akceptacji wynikającej z odmienności w grupie rówieśniczej” czy też (w przypadku osób startujących w zawodach indywidualnych) uczą „polegać na sobie oraz swoich umiejętnościach, wykorzystując zdolności motoryczne, które same musiały wypracować i podnosić ich poziom"30.

Sport powinien przede wszystkim pomagać, leczyć i integrować niepełnosprawnych z pełnosprawnymi. $\mathrm{W}$ momencie, gdy osoba niepełnosprawna zaczyna sobie lepiej radzić z własnymi ograniczeniami i akceptuje $\mathrm{w}$ jakimś stopniu ten fakt, to zauważyć można nie tylko polepszenie jej wyników w sporcie, ale również przejawy świadczące o chęci dalszego rozwoju. Mając to wszystko na uwadze, do rehabilitacji zaczęto wprowadzać elementy rywalizacji sportowej. Zorganizowane przez Ludwiga Guttmann'a zawody łucznicze (1948 r.) pokazały, że rywalizacja jest doskonałym sposobem motywacji pacjentów do walki z własnymi słabościami i ograniczeniami oraz do osiągania coraz to lepszych wyników poprzez poprawę swojej formy fizycznej. Zakończony sukcesem eksperyment stał się inspiracją do stworzenia światowego ruchu paraolimpijskiego, dzięki któremu osoby niepełnosprawne mogły realizować swoje marzenia, przezwyciężać słabości (ale też samych siebie) oraz rozwijać swoją karierę sportową ${ }^{31}$.

W Polsce pierwsza sekcja sportowa zrzeszająca niewidomych sportowców powstała w 1950 r. w Poznaniu. W wyniku działań podejmo-

${ }^{30}$ A. Mędrak, J. Piętak, T. Łosień, Wpływ aktywności ruchowej i sportu na rozwój psychomotoryczny dziecka niepetnosprawnego ruchowo, ,Journal of Education, Health and Sport" 2016, nr 6 (7), s. 125-126.

31 M. Koper,T. Tasiemski, Miejsce sportu..., op. cit., s. 114-118. 
Angelika Pawlaczyk - Aktywność społeczna i kariera zawodowa...

wanych przez Jana Dziedzica udało się zorganizować ogólnopolskie zawody sportowe, w których udział mogły brać później również osoby niepełnosprawne ruchowo oraz niesłyszące ${ }^{32}$. Igrzyska olimpijskie i paraolimpijskie uznawane są za największe i najważniejsze wydarzenia sportowe na świecie. Te drugie po raz pierwszy rozegrano w Rzymie w 1960 roku$^{33}$. Obecnie odbywają się one co cztery lata, a ich organizacją zajmuje się Międzynarodowy Komitet Paraolimpijski. Niepełnosprawni sportowcy mogą rywalizować ze sobą w wielu dyscyplinach sportowych. Stanisław Kowalik wyróżnia:

- dyscypliny sportowe letnich igrzysk paraolimpijskich: boccia, łucznictwo, lekka atletyka, jeździectwo, bowls, kolarstwo, piłka nożna siedmioosobowa, podnoszenie ciężarów, żeglarstwo, strzelectwo, pływanie, tenis stołowy, piłka siatkowa na siedząco, piłka koszykowa na wózkach, taniec sportowy na wózkach, rugby na wózkach, szermierka na wózkach, tenis na wózkach, wioślarstwo;

- dyscypliny sportowe zimowych igrzysk paraolimpijskich: curling na wózkach, narciarstwo nordyckie, hokej na lodzie, narciarstwo alpejskie ${ }^{34}$.

Warto wyróżnić jedną z najmłodszych dyscyplin letnich igrzysk. Mowa tu o wioślarstwie, w którym niepełnosprawni mogli po raz pierwszy wziąć udział w 2008 r. w Pekinie. Należy jednak podkreślić, że nie każdy może wystartować w tego typu zawodach. Ważne jest, by sportowiec oprócz dostosowanego do swoich potrzeb sprzętu spełniał także Wymogi klasyfikacyjne zaadaptowanego wioślarstwa ${ }^{35}$.

${ }^{32}$ S. Kowalik., Wykorzystanie ruchu w rehabilitacji osób niepełnosprawnych: historia idei i jej praktycznych zastosowań, [w:] S. Kowalik (red.), Kultura fizyczna osób z niepełnosprawnościq, Gdańsk 2009, s. 34-35.

33 Ibidem, s. 36.

${ }^{34}$ M. Koper, T. Tasiemski, Dostosowana aktywność ruchowa dla osób z uszkodzeniem narzq̨du ruchu, [w:] S. Kowalik (red.), Kultura fizyczna osób z niepełnosprawnością, Gdańsk 2009, s. 378-391.

35 Ibidem, s. 389. 


\section{Kategoria „ręce” czyli parawioślarstwo Jarosława Kailinga}

Sport był obecny w życiu Jarosława Kailinga już od najmłodszych lat. Tradycyjnie zaczynał od gry w piłę nożną, później był hokej i kolarstwo. Po osiągnięciu pełnoletniości sport, mimo że wciąż zajmował ważne miejsce w jego życiu, musiał odejść na dalszy plan ze względu na obowiązki wynikające z założenia rodziny. Najważniejsza była już wtedy praca. Mężczyzna wykonywał w swoim życiu wiele zawodów. Mimo, że z wykształcenia jest mechanikiem, nie ograniczał się tylko do pracy na takim stanowisku. Był on również kierowcą, murarzem, układaczem spadochronów, koordynatorem strefy spadochroniarskiej oraz szefem naziemnym w Hiszpanii. Natomiast obecnie jest zawodowym sportowcem.

Swoją przygodę ze spadochroniarstwem J. Kailing rozpoczął w wieku 34 lat. Początkowe zainteresowanie sportem przerodziło się w późniejszą pasję. Mężczyzna wychowywał się na inowrocławskich Błoniach, w pobliżu których mieści się lotnisko obsługiwane przez Aeroklub Kujawski. W związku z tym już od wczesnych lat dzieciństwa miał możliwość oglądania skoków spadochroniarskich oraz zawodów na celność lądowania. Za jeden z najpiękniejszych życiowych momentów Kailing uważa swój pierwszy skok, który miał miejsce dziewiętnaście lat temu. To właśnie wtedy zaszczepiona w nim została pasja do skakania, trwająca po dziś dzień. Osiągnięcia w spadochroniarstwie oraz bogata wiedza na temat stref spadochroniarskich przełożyła się na aktywność zawodową sportowca. Chcąc zarabiać i tym samym móc realizować siebie oraz swoje marzenia, przeprowadził się on do Hiszpanii, gdzie mimo początkowych problemów został profesjonalnym układaczem spadochronów, a później także koordynatorem strefy spadochroniarskiej i szefem naziemnym. Praca ta miała jednak nieco inny charakter, ponieważ $w$ dni powszednie Kailing pracował jako budowlaniec, a w weekendy układał spadochrony, dzięki czemu mógł skakać. Mężczyzna zapytany o ilość wykonanych w swoim życiu skoków bez wahania odpowiada: „653 i pół”. 
Angelika Pawlaczyk - Aktywność społeczna i kariera zawodowa...

Przykre wydarzenia z 2007 r. zaważyły na dalszej karierze spadochroniarza. Doznał on poważnego wypadku podczas jednego ze skoków w Sevilli. Kailing wpadł w turbulencje i doszło do podwinięcia się czaszy spadochronu. Siła upadku była tak duża, że skoczkowi nie udało się prawidłowo wylądować. Ze względu na ogromną prędkość, z jaką upadał, doznał on poważnych obrażeń ciała, wskutek czego doszło do przerwania rdzenia kręgowego. Mężczyzna w swoich opowieściach wspomina przykre doświadczenia sprzed dziesięciu lat:

Patrzyłem na swoje stopy i nie mogłem nimi ruszać. Wtedy wiedziałem, że to już koniec... Jednak po dwóch dniach dotarło do mnie, że miałem TYLKO połamany kręgosłup; żadnych innych obrażeń wewnętrznych. Najważniejsze przecież, że... żyłem!

Dla Kailinga najgorsze było to, że nie będzie mógł dalej skakać. Jednak brak możliwości skakania wcale nie oznacza, że mężczyzna pożegnał się ze swoją pasją. Przeciwnie. Nadal jest skoczkiem, tylko nie mogącym czynnie uprawiać tego sportu.

Jarosław Kailing chętnie opowiada o swoich zmaganiach z niepełnosprawnością. W szpitalu spędził 7 miesięcy, gdzie po pomyślnie przeprowadzonej operacji kręgosłupa z pomocą fizjoterapeutów wracał do zdrowia. Rehabilitacja kojarzy się mężczyźnie z niezwykłym bólem, ale uważa, że dzięki temu czuje się teraz spełniony i szczęśliwy. Warunkiem przebywania $\mathrm{w}$ tamtejszym szpitalu było dostosowanie się do zasad tam panujących, czyli $\mathrm{m}$. in. do aktywnego uczestniczenia we wszystkich zajęciach rehabilitacyjnych. Kailing wspomina, że już po ok. 3 tygodniach intensywnej rehabilitacji zauważył pierwsze postępy:

Cały czas miałem świadomość, że nie jestem tam po to, by się poddawać i załamywać. Byłem tam po to, żeby ćwiczyć, żeby zacząć chodzić (...) Po jakiś trzech tygodniach ciężkiej i bolesnej pracy zauważyłem, że bardzo wzmocniły się moje ramiona, ręce i cała górna część ciała. Pewnego dnia mój fizjoterapeuta kazał mi usiąść na wózku, podjechać do barierek i powiedział: wstań! I... wstałem. Co prawda przy jego asekuracji, ale co to było za uczucie!

Wtedy też mężczyzna utwierdził się w tym, że musi walczyć i nie może się poddawać. Gdy otrzymał swój pierwszy wózek inwalidzki, 
zaczął ćwiczyć, jednak już nie tylko pod czujnym okiem fizjoterapeutów, ale również poza specjalnie do tego przystosowaną salą. Jak wspomina - uczył się jazdy od podstaw: od schodzenia i wchodzenia na wózek po przesiadanie się na łóżko i krzesło, pokonywanie krawężników, czy nawet jazdę po ulicach Hiszpanii. Dzięki naukom i wielu radom otrzymanym od fizjoterapeutki Tere nauczył się normalnie żyć. Twierdzi, że dzięki niej nie ma teraz dla niego rzeczy niemożliwych. Kailing potrafi dzisiaj pokonać każdą przeszkodę, dlatego nie mówi o ograniczeniach, z którymi musiałby się zmagać w życiu codziennym:

Wózek w niczym nie przeszkadza. Podjadę pod każdy krawężnik. A jak się nie uda, to po prostu zejdę z wózka, wezmę go wciągnę, ponownie na niego wejdę i pojadę dalej. Nie przejmuję się tym, czy ktoś się patrzy, albo śmieje. Wiem po prostu, że muszę to zrobić.

Twierdzi, że wózek to jego nogi, dlatego muszą być takie, jak on „szybkie i sprawne”. Dlatego ćwiczył coraz intensywniej, aż w końcu po siedmiu miesiącach został wypisany do domu. W dalszym procesie rehabilitacji poznawał wielu ludzi, w tym szermierzy, którzy zainspirowali go do działania i zajęcia się sportem zawodowo. Kailing chciał już nie tylko poprawiać swoją sprawność, ale również współzawodniczyć z innymi osobami i realizować swoje marzenia. Dlatego też z wózka inwalidzkiego postanowił regularnie przenosić się na ergometr wioślarski. Po roku zauważył, że osiągnął to, na czym mu najbardziej zależało - wzmocnił swojego nogi, pojawiły się mięśnie. Mimo 70-procentowego uszczerbku na zdrowiu stwierdził „chcieć to móc”. Dlatego postanowił znaleźć klub, w którym będzie mógł zająć się wioślarstwem zawodowo. Po trzech miesiącach wystartował $\mathrm{w}$ pierwszych zawodach, w których zajął drugie miejsce, zdobywając tym samym srebrny medal. W Sevilli podczas jednego z treningów na rzece miał okazję poznać polską kadrę narodową parawioślarzy i tak rozpoczęła się jego kariera. Ze względów osobistych musiał porzucić trwające już prawie 5 lat treningi w Hiszpanii i wrócić do Polski. Jednak dzięki obecnemu trenerowi - Tomaszowi Kaźmierczakowi - mógł da- 
Angelika Pawlaczyk - Aktywność społeczna i kariera zawodowa...

lej rozwijać się pod jego czujnym okiem w KSI „Start Szczecin”. Na sukces nie czekał długo. Po przyjeździe wziął udział w XXV Mistrzostwach Polski na Ergometrze Wioślarskim, na których zajął pierwsze miejsce w kategorii Niepełnosprawni mężczyźni Ręce (AS). Podczas Mistrzostw Europy na Węgrzech znalazł się tuż za podium. Jednak niedługo po tym $\mathrm{w}$ organizowanych $\mathrm{w}$ Bostonie zawodach został wicemistrzem świata w kategorii AS. Oprócz osiągnięć na ergometrze wioślarskim Jarosław Kailing zdobywa również medale na wodzie. Jednym z ważniejszych osiągnięć jest uplasowanie się na ósmej pozycji podczas Pucharu Świata w Wioślarstwie w Poznaniu. Obecnie sportowiec przygotowuje się do kolejnych Mistrzostw Polski. Jednak jego największym marzeniem jest wystartowanie w Igrzyskach Olimpijskich w Tokio w 2020 r. Będąc o krok od wzięcia udziału w tegorocznej paraolimpiadzie $w$ Rio de Janeiro, otrzymał jeszcze większą motywację, nie poddaje się i dąży do osiągnięcia wyznaczonych przez siebie celów.

\section{Podsumowanie}

Niepełnosprawni muszą zmagać się z wieloma trudnościami w życiu codziennym. Jednak niezwykle ważne jest podjęcie walki i zmierzenie się ze swoimi lękami i słabościami. Ogromne znaczenie w powrocie do normalnego życia ma rehabilitacja. Jej celem jest przede wszystkim usprawnienie osoby niepełnosprawnej. W procesie rehabilitacji ważną rolę odgrywa sport. Dzięki niemu osoba niepełnosprawna ma szansę poprawić swoją sprawność, wrócić do prawidłowej formy fizycznej i psychicznej, a w późniejszym procesie móc także współzawodniczyć z innymi osobami podczas różnego rodzaju zawodów.

Jarosław Kailing jest przykładem osoby, która mimo poważnego urazu kręgosłupa nie zrezygnowała ze swojej pasji. Sport od zawsze był dla mężczyzny sposobem na życie. W powrocie do normalnego życia pomagała mu rodzina, znajomi oraz fizjoterapeuci. Dzięki ich wsparciu uwierzył w siebie, w swoje możliwości i rozpoczął walkę. 
Początkowo była to tylko walka z własnymi słabościami, jednak później przeniosła się ona na wodę, gdzie rozpoczęła się już walka o marzenia. Sportowiec - jak sam twierdzi - oddałby wszystko, żeby wrócić do życia przed wypadkiem. Jednak zmuszony do zaakceptowania swojej niepełnosprawności i nauczenia się z nią żyć, zaczął poznawać swoje ciało i możliwości. Wiedział, że granicą jest tylko ból, który z kolei chciał za wszelką cenę przezwyciężyć. Pierwsze sukcesy niosły za sobą kolejne - te mniejsze i większe: „Potrafię zrobić kilka kroków o kulach. Z perspektywy czasu to naprawdę duży sukces. Kiedyś przecież nie mogłem nic...."

Zapytany o stosunek otoczenia do osób niepełnosprawnych przyznaje, że ludzie boją się patrzeć. Kiedyś sam się bał. Dlatego teraz, kiedy porusza się na wózku, stara się pokazać wszystkim, że niepełnosprawność wcale nie oznacza czegoś gorszego.

"Chcieć to móc" - tymi słowami mężczyzna próbuje motywować innych niepełnosprawnych (którzy w przeszłości ulegli wypadkowi) do działania. Stara się rozmawiać z nimi, dawać rady i wspierać, tak jak kiedyś robili to jego bliscy. Wie, że dzięki temu człowiek może nie tylko przezwyciężyć ból i wygrać walkę z własnymi słabościami, ale przede wszystkim rozwijać się, dążyć do wyznaczonych celów i spełniać własne marzenia.

\section{Bibliografia:}

Belzyt J., Niepełnosprawność - Edukacja - Dorosłość: studium przypadku osoby ociemniałej, Wyd. Impuls, Kraków 2012.

Czerw-Bajer M., Duda W., Kukla D., Osoby niepełnosprawne w systemie edukacji i poradnictwa zawodowego, Wyd. Difin, Warszawa 2011.

Karaś M., Niepełnosprawność, od spojrzenia medycznego do społecznego i Disability Studies, „Przegląd Prawniczy, Ekonomiczny i Społeczny” 2012, nr 4.

Koper M., Tasiemski T., Dostosowana aktywność ruchowa dla osób z uszkodzeniem narzq̨du ruchu, [w:] S. Kowalik (red.), Kultura fizyczna osób z niepełnosprawnościq, Gdańskie Wydawnictwo Psychologiczne, Gdańsk 2009. 
Angelika Pawlaczyk - Aktywność społeczna i kariera zawodowa...

Koper M., Tasiemski T., Miejsce sportu w procesie rehabilitacji osób niepełnosprawnych fizycznie, „Niepełnosprawność - zagadnienia, problemy, rozwiązania" 2013, nr 3 (8).

Kotlarska-Michalska A., Człowiek niepełnosprawny jako „inny” w ujęciu koncepcji socjologicznych $i$ wiwietle badań socjologiczno-psychologicznych, „Roczniki Socjologii Rodziny” 1999, t. 11.

Kowalik S., Wykorzystanie ruchu $w$ rehabilitacji osób niepełnosprawnych: historia idei i jej praktycznych zastosowań, [w:] S. Kowalik (red.), Kultura fizyczna osób z niepełnosprawnością, Gdańskie Wydawnictwo Psychologiczne, Gdańsk 2009.

Kowalik S., Psychospołeczne podstawy rehabilitacji osób niepełnosprawnych, Wyd. Interart, Warszawa 1996.

Majewski T., Szczepankowska B., Rehabilitacja zawodowa osób niepełnosprawnych, [w:] A. Ostrowska, B. Szczepankowska (red.), Problem niepełnosprawności w poradnictwie zawodowym, Wydawnictwo i Zakład Poligrafii Instytutu Technologii Eksploatacji, Warszawa 1998.

Mędrak A., Piętak J., Łosień T., Wpływ aktywności ruchowej i sportu na rozwój psychomotoryczny dziecka niepełnosprawnego ruchowo, „Journal of Education, Health and Sport" 2016, nr 6 (7).

Otrębski W., Różnowski B., Sytuacja psychologiczna osób z niepełnosprawnościq na rynku pracy, Wyd. Instytut Rynku Pracy, Lublin 2008.

Sosnowska J., Znaczenie podjęcia aktywności zawodowej $w$ życiu osoby niepełnosprawnej, „Studia Gdańskie. Wizje i rzeczywistość” 2011, t.8.

Syrek E., Niepełnosprawność - wybrane aspekty jakości życia i promocji zdrowia, [w:] E. Nycz (red.), Niepełnosprawni czy sprawni inaczej - partnerstwo zamiast wykluczenia społecznego, Wyd. Instytut Śląski, Opole 2003.

Wolski P., Niepełnosprawność ruchowa: między diagnozq a działaniem, Centrum Rozwoju Zasobów Ludzkich, Warszawa 2013.

Zespół Małopolskiego Obserwatorium Polityki Społecznej, Praca i integracja społeczna osób niepełnosprawnych w województwie małopolskim, Kraków 2011.

\section{Netografia:}

http://www.cbe.ahe.lodz.pl/

http://www.niepelnosprawni.pl/ledge/x/1808 


\section{Etos nauki - między klerkowskim a eksperckim modelem nauki ${ }^{1}$}

\section{Ethos of science - between clerk and expert models of science}

\section{Streszczenie:}

Celem opracowania w warstwie poznawczej jest przedstawienie zmian, jakie dokonały się w rozumieniu zadań uczelni oraz roli uczonych; zmian obejmujących przejście od klerkowskiego do eksperckiego modelu uprawiania nauki, przy czym każdy model legitymuje odmienny zestaw norm, ukonstytuowany przez inne hierarchie wartości. Co się tyczy warstwy aplikacyjnej tego opracowania, to celem jest pokazanie sposobu lokowania tradycyjnych i nowoczesnych norm w misji i strategii konkretnej uczelni, a dokładnie Åbo Akademi w Vaasa, w Finlandii. Etos nauki oraz praktyka jego kultywowania stały się podstawą etnograficznego studium przypadku nad doświadczaniem sukcesu w nauce przez studentów studiów doktoranckich - doktorantów edukacji tejże uczelni. Zaprezentowany aksjonormatywny profil badanej uczelni jest przykładem eklektycznego modelu nauki, realizującego zarówno akademicki, jak i post-akademicki tryb wytwarzania wiedzy naukowej. Rozpoznany stan rzeczy dowodzi, iż uczelnia może być miejscem sprzyjającym realizacji tak badań podstawowych, jak i stosowanych.

Słowa kluczowe: aksjonormatywny wymiar nauki, etos nauki, klerkowski i ekspercki model nauki, akademicki i post-akademicki tryb wytwarzania wiedzy, arystokratyczny i rzemieślniczy styl badawczy

1 Zaprezentowane w niniejszym opracowaniu ustalenia są wycinkiem etnograficznego studium przypadku nad doświadczaniem sukcesu w nauce przez studentów studiów doktoranckich - doktorantów edukacji Åbo Akademi w Vaasa, w Finlandii. Projekt badań jest podstawą rozprawy doktorskiej, której promotorem jest prof. zw. dr hab. Urszula Ostrowska. 
Katarzyna Grzesiak - Etos nauki...

\begin{abstract}
:
The cognitive purpose of this paper is to display changes of defining university tasks and a scholar role; the changes which refer to the evolution of a science model, from clerks to experts, whereas each of the models legitimizes different set of standards constituted by diverse hierarchies of values. In regards to the purpose of the application, the text presents the placement method of traditional and modern standards in the mission and strategy of a specific university, namely Åbo Akademi University in Vaasa, Finland. Both ethos of science and their cultivating practices are the basis of the ethnographical case study on doctoral students doing PhD in education at ÅA. In addition, the study demonstrates how they experience success in science. The presented axionormative profile of the examined university is an example of implementing an eclectic scientific model which fulfils the academic and post-academic modes of producing scientific knowledge at the same time. The disclosed research case proves that universities might be a shared space for coherent coexistence of both basic and applied sciences.
\end{abstract}

Keywords: axionormative dimension of science, ethos of science, clerk and expert models of science, academic and post-academic mode of producing knowledge, research styles of aristocrats and craftsmen

\title{
Aksjonormatywny wymiar nauki
}

Nauka jest integralną częścią ludzkiej kultury². W ujęciu genetyczno-strukturalnym nauka stanowi ważne narzędzie badania i opisu elementów tworzących kulturę, równocześnie będąc jednym z jej źródeł. Zaś w ujęciu normatywno-psychologicznym nauka stanowi nośnik wartości i wzorów postępowania, a jednocześnie doskonali sposoby internalizacji norm kulturowych ${ }^{3}$.

Od kiedy nauka osiągnęła pełnię swej instytucjonalizacji - to jest od czasu upowszechnienia idei uniwersytetu liberalnego, którego rzeczywistą kwintesencją jest powołany na początku XIX wieku i funk-

\footnotetext{
2 A. Lekka-Kowalik, Nauka, [w:] K. Chałas, A. Maj (red.), Encyklopedia aksjologii pedagogicznej, Radom 2016, s. 646.

3 E. Włodarczyk, Kultura, [w:] T. Pilch (red.), Encyklopedia pedagogiczna XXI wie$k u$, T. 2, Warszawa 2003, s. 952.
} 